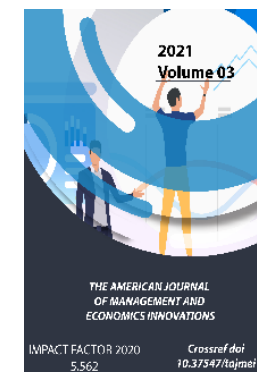

Journal Website: https://theamericanjou rnals.com/index.php/ta jmei

Copyright: Original content from this work may be used under the terms of the creative commons attributes 4.0 licence.

\section{Factors Influencing The Formation Of International Budget Accounting Systems}

Ismanov I.N.

Doctor Of Economic Sciences, Professor, Fergana Polytechnic Institute, Fergana, Uzbekistan

Axmadaliev B.

Researcher, Fergana Polytechnic Institute, Fergana, Uzbekistan

\title{
ABSTRACT
}

This article discusses the budget system, the areas it covers, the national accounting systems of countries in international practice and their specific features. Also discussed are the Continental European model (development of the accounting system through legislative initiative), the British model (development of accounting through the initiative of consultant accountants) and the United States model (development of accounting through the influence of general accountants and engineers).

\section{KEYWORDS}

Budget, budget system, state budget, public policy, national accounting, accounting model, regional model, Anglo-Saxon model, international model, macro model, influencing factors, political factors, religious factors, economic factors.

\section{INTRODUCTION}

According to the research of Christopher and Robert Parker (1995), countries are divided into economic categories based on accounting models. According to the results of this analysis, the international models of accounting were in the following order: British Commonwealth Model (Australia,
Bahamas, Ireland, Fiji Islands, India, Jamaica, Kenya, Malaysia, Netherlands, New Zealand, Pakistan, Papua New Guinea, Zimbabwe, Singapore, South Africa, Sri Lanka, Trinidad \& Tobago, United Kingdom); - Model of the United States (Canada, Indonesia, Japan, Marshall Islands, Mexico, Panama, Philippines, 
United States); - Model of the Soviet Union (Azerbaijan, People's Republic of China, Mongolia, Russia, Uzbekistan); - Continental European model (Belgium, Cambodia, France, Germany, Italy, Spain, Sweden, Switzerland, Viet Nam, Venezuela); - Latin American model (“Castilian model”) (Argentina, Bolivia, Chile, Colombia, Ethiopia, Paraguay, Peru, Uruguay).
Gureva (2009) favoured the use of classical models (continental and Anglo-American models) in the organization of accounting, and the researcher cited the order of transactions between the state and business entities based on the chart of accounts. International standards of financial accounting, on the other hand, suggest that this is the result of a combination of classical models.

\section{MATERIALS AND METHODS}
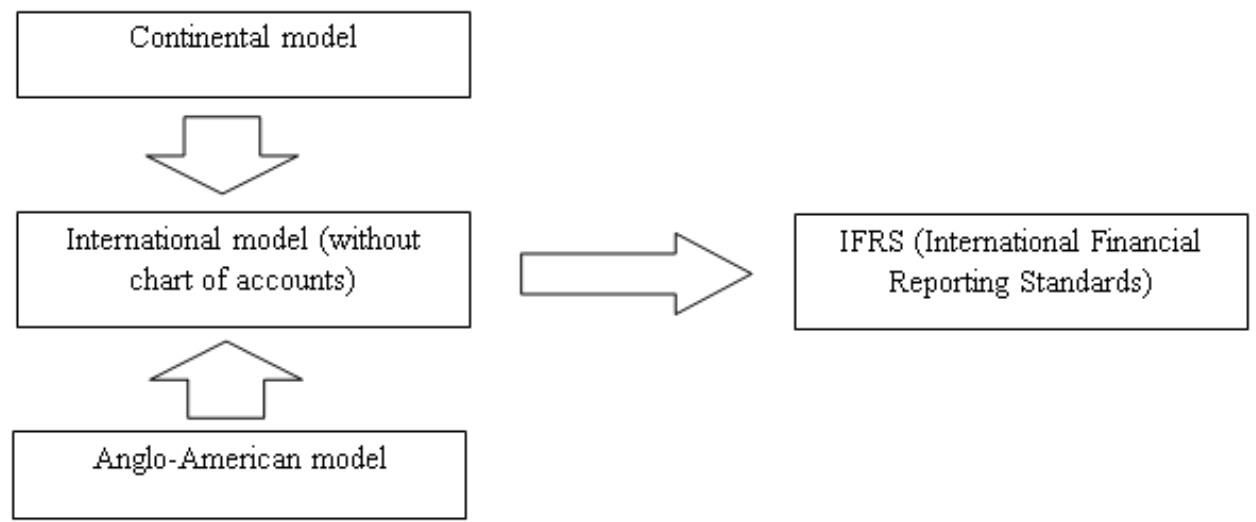

Figure 1 Basic classical models of accounting (Gureva, 2009)

According to Shigun (2011), countries are divided into the following groups according to their geographical location and methodological approach to accounting regulation:

- British-American model (Anglo-American, Anglo-American-Dutch);

- Continental model (European);

- South American model (Latin American);

- The model according to international financial accounting standards (international model);
- The model of the former socialist countries and the CIS countries;

- Transition system model (reforming the country's accounting system by bringing it closer to one of the Anglo-American or continental models or by bringing the financial accounting closer to international standards).

In the scientific revision of the classification of accounting into types, macro models are evaluated as follows: 


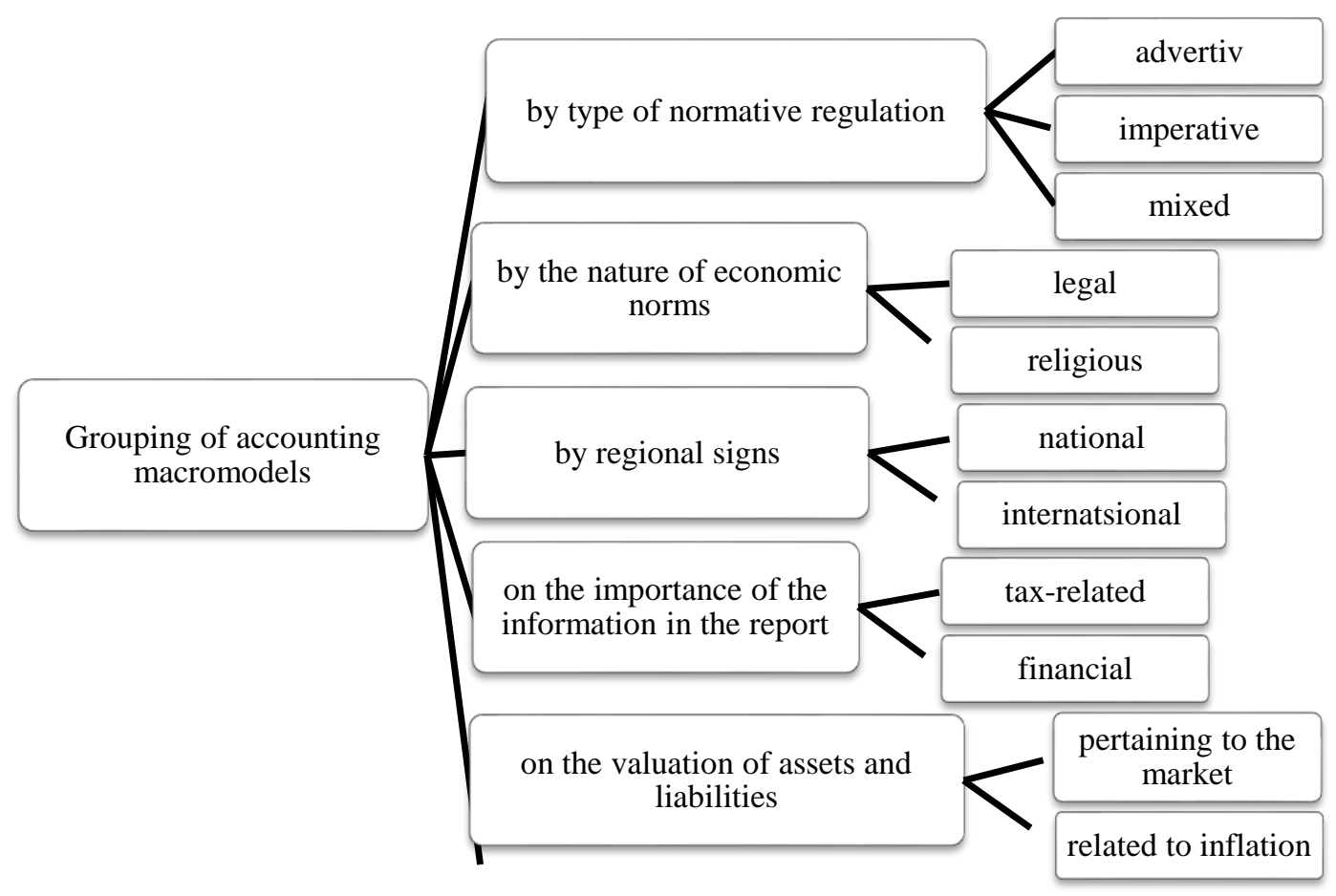

Figure 2. Grouping of accounting macro models. (Shigun, 2011)

As for the grouping mentioned above (Figure 2 ), the adversative model is derived from the Latin word adverto, which means to direct, to strive for.

This model is of a professional nature of accounting regulation in the country and requires the use of accounting standards developed by a professional accounting organization. Such a model is available in countries such as the United States, Great Britain, Canada, Australia, Israel, India, New Zealand, and the Philippines. In this case, the accounting standards developed by the organization of professional accountants are used as a rule in agreement with the state legislature. The imperative model is derived from the Latin word imperativus, which means to pass judgment. Accounting is a regulation through legislation, in which case these laws regulate the accounting of all organizations in the country. Countries such as Germany, Austria, France, Switzerland, Italy, Belgium use this model. Ukraine also uses a system of state regulation of accounting. Mixed model - the principles of preparation and submission of the report, the organization and maintenance of accounting are developed and implemented jointly with the participation of the state and the organization of professional accountants.

The legal model provides for the use of rules developed based on international and national legal systems in the process of regulating accounting standards. Such legal norms have historically been based on the rules of business relations and are used in many countries around the world. Religious model - in which economic norms are formed based on religious principles and divine ideas. Such a model is prevalent mainly in Islamic countries and countries on the African continent. The national model is formed in each country of the world based on its internal characteristics. International model - this model is formed mainly in the process of solving global 
economic problems and is based on international standards of financial accounting. Tax model - the importance of the information provided is mainly the openness, transparency in the calculation and payment of taxes. Currently, this model is used in France, Italy, Spain, Belgium, Latin America and Ukraine.

Financial model - the importance of financial accounting and reporting in the face of tax data.

Inflation model - this model is mainly used in economically underdeveloped countries with high inflation rates, which requires constant adjustment of accounting data to price level changes. The inflation model is maintained in Brazil, Argentina, Bolivia, Paraguay, Peru and other South American countries.
Market model - this model is mainly used in countries with developed market economies, countries with stable political systems, almost stable price levels and stable national currencies, and no adjustment of reporting data to the inflation rate. This model is used in countries of the European continent, the United States and the United Kingdom, and elsewhere. Naturally, changes in the existing political, economic and legal conditions in the countries will lead to changes in the principles of accounting. As a result of the influence of these enumerated conditions, the accounting rules of the states are also formed differently. As an example, Lymar (2017) argues that the following internal and external factors influenced the formation of the Chinese accounting and reporting system (Fig.3).

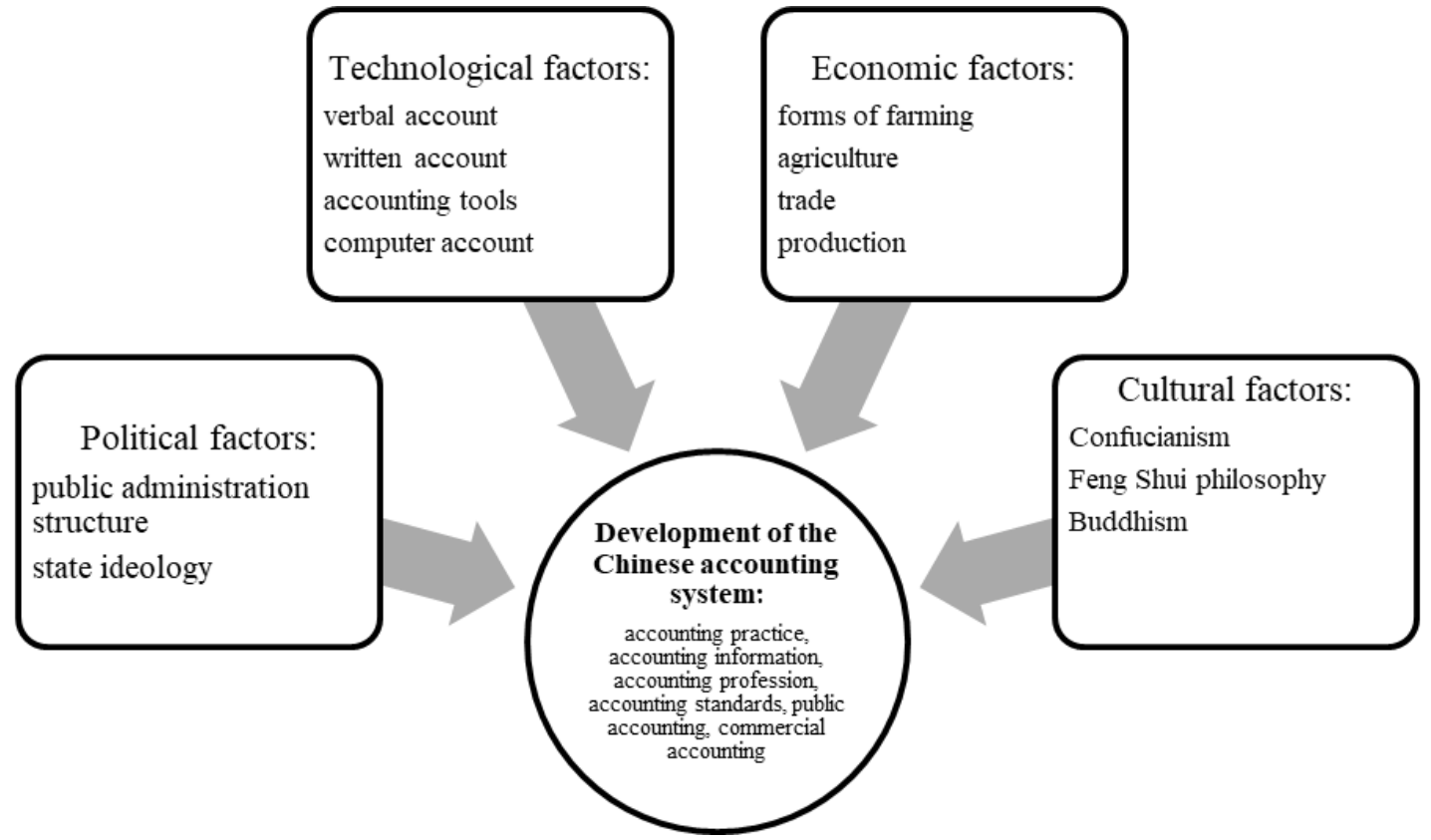

Figure 3 Factors Affecting the Chinese System (Lymar, 2017)

Looking at foreign experience, Kucherov and Shibilova (2012) say that budget accounting plays a key role in the formation and distribution of budgetary financial resources at different levels. Given the history of U.S. budget accounting standards, the American accounting system has several development trends in a market economy. The main feature is that accounting standards are developed by non-governmental organizations. Chan (1996), a scholar who has researched the classification of Chinese accounting, explains his views as follows. China's accounting system has undergone a series of reforms in recent years, 
and as a result, the economic system has been transformed from the current centralized planned economy to a socialist market economy. This picture shows the organizations and functions of the Chinese government. General Law According to the Constitution, the Chinese state has property and management functions. The Chinese state also owns its own national resources and commercial and

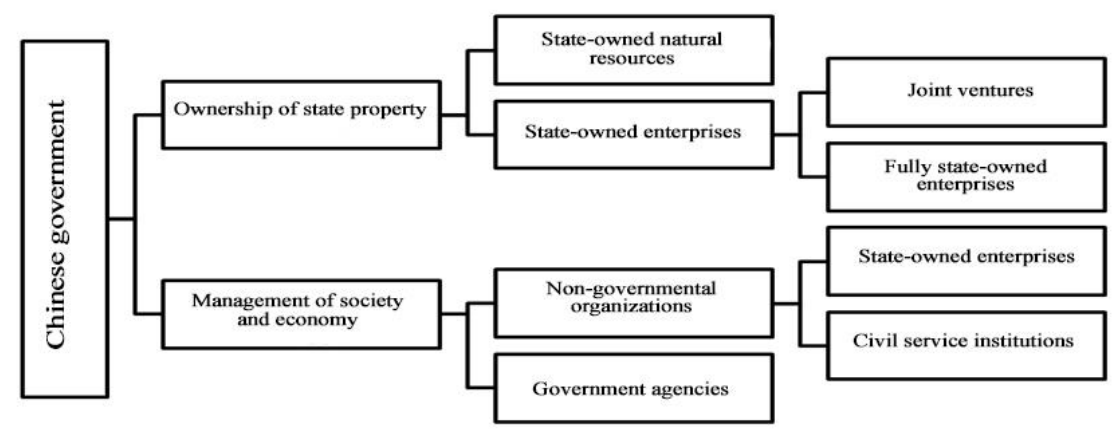

Figure 4. Government and Budget Control in China (Chan, 1996) industrial enterprises (which are partially or wholly state-owned). The Chinese state is responsible for governing society and the economy. The second function is to implement public policy through public administration (state-owned) enterprises and public service institutions and public administration agencies.
The indicators on the right side of the picture show that the state-controlled budget control for organizations producing goods and services in the public sector is too strong, while in state-owned enterprises we see weak (minimized) budget control. In China, public sector organizations are called "units". This means that, regardless of the size of the organization, it is a large body - a component (unit) of the state. The state of China is governed by the State Council, which is overseen by the National People's Congress. In the Chinese public sector, units fall into three main categories: administrative units, institutions, and enterprises. Administrative units (Jingdezhen danwei) formulate and implement public policy. These units are governed by management and supervisors, offices. Nonprofits, on the other hand, are generally referred to as service-oriented institutional units, or institutions (Shia) for short. These units include state-owned educational institutions, health care organizations, and social service agencies. Several large state-owned or state-owned commercial and industrial enterprises, or in short, enterprises, can be called enterprises, which include manufacturing concerns, trading companies, and financial institutions.

In China, the concept of "budget accounting" includes the terms "government accounting" and "nonprofit accounting" in the United States. In China, the public sector is divided into decentralized groups through the following 3 types of responsibility centres: cost centres, breakeven centres, and profit centres. These centres are directly related to administrative units, institutional units, and state-owned enterprises that are public sector organizations in China. In general, the budget account is a tool for monitoring and managing budget execution. 


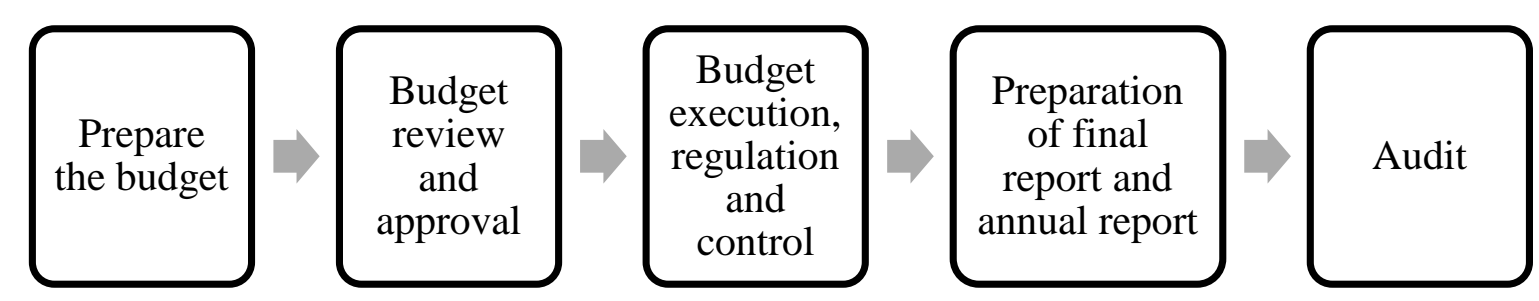

Figure 5. Budget Process in China

The picture above shows the stages of Public Finance Management in China.

The initial stage is the preparation of the budget, and the next is the stage of consideration and approval. The budget execution process is followed by the recording of financial transactions and transactions. And at the end of the financial year, books are closed, annual reports are prepared and audited (checked).

The Chinese state budget consists of a combination of the central government budget and the provincial budget (local government budgets). These budgets are called" general budgets "(John yushuan) and differ from" holistic(unit) budgets " (danwei yushuan). When viewed logically, the concept of a budget accounting system is drawn up from the concepts of" General Budget Accounting "and" units budget accounting". The budget system in China consists of five different tier budgets, corresponding to five different levels of governorship. These are divided into Central, Provincial, urban/district, suburban and rural (settlement). When drawing up the state budget, the lower general rural budget $\rightarrow$ general municipal budget $\rightarrow$ general provincial budget and these totals constitute the general budget of the local government. The budget of the local government and the general budget of the central government are summarized and form the state budget. Organizations that depend entirely on the provision of a high level of government budget are referred to as "full budget management units". There are some organizations (hospitals and educational institutions) that are allowed to receive payment (fare) for their services, which themselves cover some of their expenses.

Such organizations are called "differential budget management units". Vanihoyat said that there are still organizations that cover all their expenses through their own deductible income, which are considered independent, economic organizations in the account and call them "budget management units that cover their own payment".

Established budget laws in China have been meticulously developed by the Ministry of Finance through regulatory rules. The main task of the Budget Management Board in the Ministry of Finance is to develop rules that are subordinate to the accounting rules and procedures of accounting. The advantage of this system is that it ensures the interoperability between budgeting and accounting as well as enables the implementation of the control function of the state. At each level, there are accounting departments in administrative units and institutions. The Chinese budget account is characterized by its reliability in the current national policy. China's budget account itself 
reflects the political ideal of public policy concerns. The budget of the government is an integral part of the economic development plan aimed at achieving national goals, whose specific directions are set by the Communist Party of China. The budget is the law adopted by the people's National Congress. Budget accounting performs the function of the control function of the budget through the transfer (directing) of budgetary resources. In China, the Audit Department is part of the State Council, and its chief (Auditor-General) will report to the General Assembly. The Chinese state has developed a plan of Accountancy and this plan of Accountancy is equally valid for the management units and institutions of the governorship at each level. Accounting procedures and forms of reports are also defined. In 1990, under the Ministry of Finance (Ministry of finance), the Chinese budget accounting society was established, which greatly helps the society and its local departments in the execution and observance of the adopted uniform accounting policies and procedures. Every month on the part of the society, a magazine called "Budget Accounting" is published, bringing to the public the siyy decisions (announcements, news). Since 1992, the national system of accounts, which checks the level of professional knowledge, has also established requirements for budgetary accounting. History's budget accounting also covers the accounts of governorship management agencies, the accounts of state institutions and the accounts of state enterprises. As a result of economic reforms, the accounts of state enterprises were allocated from the budget account, and its standards are also being developed by the Ministry of Finance.

The Budget Law of the people's Republic of China was issued in 1994 year and entered into force from the 1995 Year 1 January. This law describes in detail all the processes of the management of Chinese public finances. The law consists of 10 Chapter 79 articles, which include: the jurisdiction of budgetary control, budget revenue and expenditure, preparation of budget, review and approval of the budget, execution of the budget, regulation of budget, final reports, Control and legal responsibility. Revenues from the budgets of Central and local governorates are allocated. According to the law, the budget is presented to the people's Congress. Under the law, the people's Congress reviews and approves the budget draft, submitted by the management departments. Review and approval, in turn, requires the regulation of the budget., two times a year receive reports on budget execution, review and approves the draft final reports.

\section{RESULTS AND DISCUSSION}

According to the law, the source of central government revenue is formed mainly from consumption tax revenues and is financed for national security and foreign policy; for administrative expenses of the central government; to implement large-scale projects and to develop infrastructure; for scientific and technical projects of national character; for higher education institutions. The source of local government revenue is mainly formed from business activity taxes, real estate taxes, personal income tax, which is used to finance the following expenses; for social security programs; for cultural, educational, health and sports expenses; for local government management costs.

In addition, corporate income tax, natural resource tax and value-added tax are distributed equally between the central and local governments. China's fiscal policy is set out in this law as follows: first, local 
governments are not allowed to issue bonds and work with deficits. Central governments are also not allowed to work with deficits.

However, they can borrow for capital investment programs. Second, budget decisions should be guided by economic principles. In order to achieve general wellbeing, it is necessary to develop regions with low economic potential. Third, the projected income should be directly related to the growth rate of the Gross National Product.

Fourth, the budget for a particular year should be based on the results of last year's and current projects, with a budget reserve of 1-3 per cent for emergencies.
In China, since 1949, the budget has been a "single budget system", according to which there is no difference between operating costs and capital expenditures. Since 1992, the Chinese government has divided budget system expenditures into recurring operating expenditures and expenditures to achieve economic development. He called the system a "dual budget system". That is, from this combination, it can be seen that the government has divided recurring budgets and capital budgets into separate types. Later, this combination was transformed into a multifaceted budget. The figure below shows the process of transition from a unilateral budget to a multilateral budget.

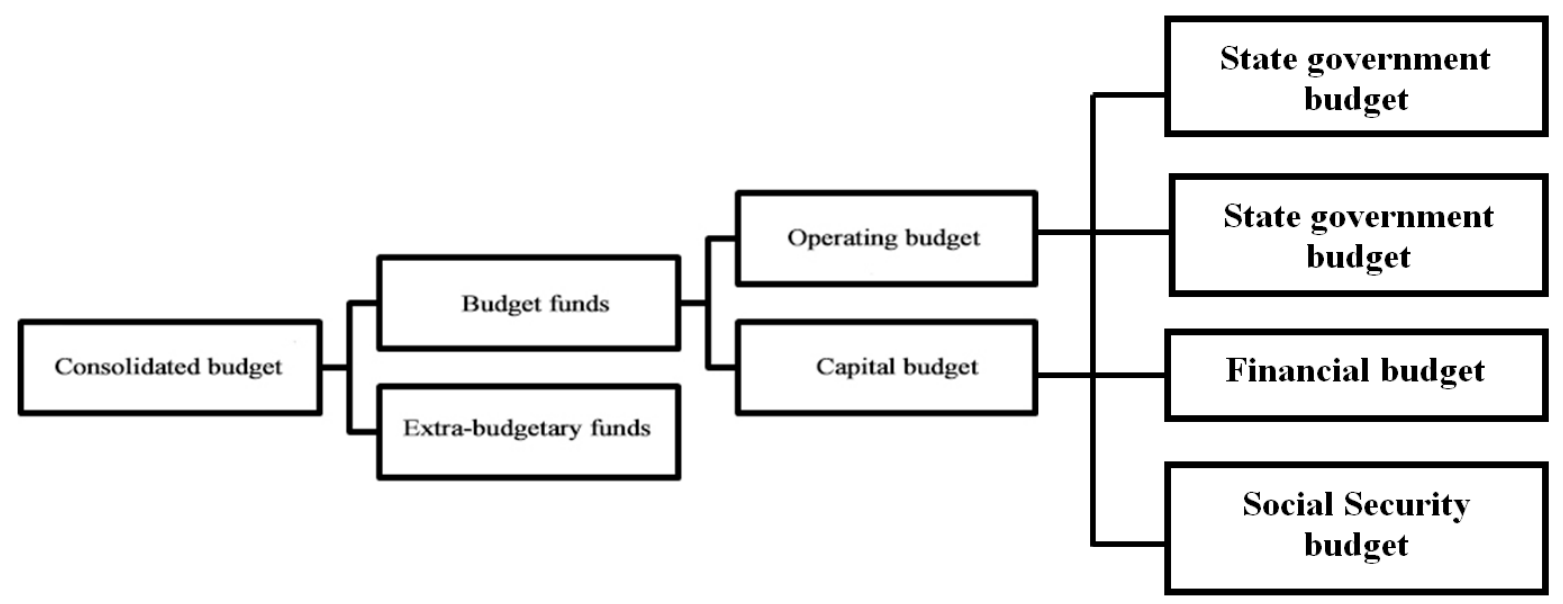

Figure 7. The transition from a unilateral budget to a multilateral budget (Chan, 1996)

According to the picture above, the state government budget is an operational, recurring budget that is funded by tax revenues. The state property management budget is financed from the funds received from the use of state property. The financial budget is understood mainly as the expenses incurred on the issuance of securities, debt service and credit activities, which reflect the debt obligation. The social security budget is formed from the contributions of the pension fund and the unemployment benefit (insurance) fund and is financed through administrative units. Here we can see the following as the specific advantages of a multilateral budget: it reveals the functional classification of the budget, ensures budget transparency, increases the efficiency of the use of budget funds. Following the drafting of the Budget Law, in September 1994, the Bureau of Budget Management of the Ministry of Finance held an international symposium on "Public Accounting and Treasury Management", according to which the standards of public accounting and budget accounting were discussed. 
Budget accounting is a phrase that corresponds to the definition of accounting of government agencies and government agencies.

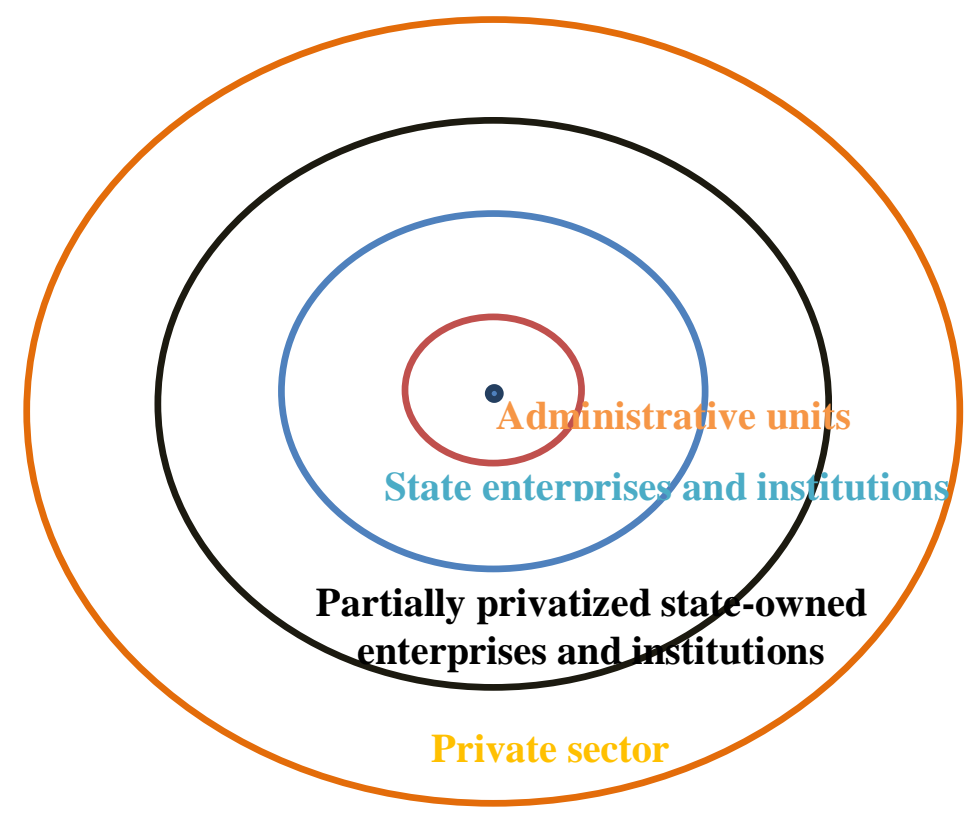

Figure 8. Centralized Circles (Chan, 1996)

In the picture above, we can see the existing macroeconomic and social order in China through "concentric circles". At the heart of Chinese governance are administrative units, which are the apparatus that develops and executes political documents, and which includes various organizations. As each circle moves away from the centre, direct state control decreases and the last Private Sector organizations are controlled only by by-laws issued by the state. From these "centralized circles," we can see that the state budget is not only centralized funds but also manages and controls every economic activity in China. The closer you get to the centre, the more budget control you get.

\section{REFERENCES}

1. Ostonaqulov M. (2009) Some Issues in Budget Accounting Reform.
Economics and Finance, No. 3, pp. 2028b.

2. Ismanov I. N. (2017). The need for the transformation of the accounting system into international financial reporting standards. Economics and Finance, No. 3, pp. 38-44b.

3. Mehmonov S.U. (2012) Budget Accounting: A Study Guide. $-\mathrm{T}$.: "Science and technology".

4. Chan J.L. (1995) "Budget accounting in China: continuity and change", Research in Governmental Nonprofit Accounting, 9-соH, 147-1746.

5. Robert M.J.(1950) "Three Major Concepts in Governmental Accounting Theory", The Accounting Review, 3(952)- $\mathrm{COH}, 307-3146$.

6. OECD (2017) Budget Transparency Toolkit, http://www.internationalbudget.org/o pening-budgets/open-budget- 
initiative/open-budget-

survey/Budgeting-Transparency-

ToolkitOECD2017.pdf

7. Ismanov, I. N., \& Mo'ydinov, E. D. (2020). Audit of events after the reporting date. Academicia: An International Multidisciplinary Research Journal, 10(10), 966-974.

8. Ismanov, I. N., \& Moydinov, E. D. (2020). Concept of importance in audit planning and execution. Academicia: An International Multidisciplinary Research Journal, 10(7), 381-391.

9. Исманов, И. Н., \& Маткаримов, А. (2017). Preparation of qualitative financial reports for the development of investment attractiveness of the economy of uzbekistan. In Бухгалтерский учет: достижения и научные перспективы XXI века (рр. 138-144).

10. Najmiddin, T., \& Saidalohonovich, K. A. (2020). About the origin and development of the universe, man, and accountability. Journal of Critical Reviews, 7(13), 1763-1769.

11. Atabaeva, Z. A., \& Khojaev, A. S. (2020). Investment activity and analysis of investment projects. ISJ Theoretical \& Applied Science, 5(85), 714-720.

12. Azizkhon, K. (2017). The peculiarities of statistical analysis on fruit and vegetable farming (Fergana region is as an example). Бюллетень науки и практики, (8 (21)).

13. Hakimova, S., Habijonov, S., \& Hojaev, A. (2018). Statistical prognosis of the production of fruits and vegetables grown by farmers in the Fergana region. Bulletin of Science and Practice.

14. Khojaev, A. S., \& Akramova, N. M. (2017). The ways of development and statistic analysis of farmers'activities specialized in fruit-vegetables production in the ferghana region. In Экономика, управление и право: инновационное решение проблем (pp. 45-47).

15. Tam, C., da Costa Moura, E. J., Oliveira, T., \& Varajão, J. (2020). The factors influencing the success of ongoing agile software development projects. International Journal of Project Management, 38(3), 165-176. 